\title{
E-Learning During Covid-19: A REVIEW OF LITERATURE
}

\author{
Ana Nurdini Sharin \\ University of Malaya, Malaysia \\ aim180003@siswa.um.edu.my
}

\begin{abstract}
A dramatic change has been required on how the students are getting their education due to the novel coronavirus (COVID-19) outbreak in Malaysia. Not only did students have to maintain a social distance from their peers and family, but students also must adapt with online learning. Remote learning has become the norm to avoid the wide-reaching and transferable contagious disease. The sudden outbreak disrupted the education system worldwide and forced educators to switch to online mode of teaching especially on University level. Some students acknowledge and are ready for online learning. However, some are reluctant to shift from traditional learning to online learning. There seem to be several methods where educators could help to make the virtual education experience more engaging and efficient. Therefore, several articles on enhancing online learning and teaching were summarized. Most of the existing research suggests that the adaptation of distance learning was a brilliant choice. Nevertheless, study showed that some students tend to detest online learning due to the challenges of personal and technological difficulty issues. Besides, distance learning has also been found to be related to psychological impact such as stress and anxiety. Moreover, the existing research discovered that online learning could give psychological impacts in correlation with the challenging learning process. This paper summarizes relevant scholarly articles, identifies ideas and the need for further study.
\end{abstract}

Keywords: COVID-19, online learning, readiness, challenges, psychological impacts.

\section{INTRODUCTION}

A sudden outbreak of a lethal disease caused by the CoronaVirus (SARS-CoV-2) named Covid-19 was reported in Wuhan, People's Republic of China. Then, it was confirmed as a global pandemic by the World Health Organization (WHO). Millions of people were infected, and it triggers nationwide lockdowns. People have been permitted to be outside of their homes for crucial purposes such as purchasing household items, and anything related to medical purposes. The global economy has been profoundly affected by the lethal and contagious Corona Virus outbreak, also known as Covid-19. The education sector has greatly been affected by this crisis and yet this is expected to extend globally across the education sector (Dhawan, 2020). Any programs including schools and colleges programs were instructed to be transferred online. Covid-19's pandemic outbreak forced many educational institutions to 
remain closed temporarily. Different schools, colleges and universities have stopped teaching in person. It is questionable, as per the study evaluation, to return to physical learning shortly at any moment (Dhawan, 2020). The Covid-19 crisis would set up the institutions that were previously unwilling to switch and accept modern technology. This crisis would reveal the valuable side of online learning and teaching. E-learning appears in the middle of this turmoil as a victor. However, there are several arguments associated with online learning.

During the pandemic, numerous countries worldwide have implemented different methods and approaches to continue the education process. Educational units are trying to find alternatives to cope with this tough situation. These circumstances make us aware of the urgent needs for academic institutions (Rieley, 2020). Online education refers to a sort of learning and teaching situation. In order to access learning materials in which the learner is at a distance from the teacher or instructor, the learner uses technology. The learner uses devices to interact with the teacher and other students, and learners are offered some kind of guidance or assistance (Anderson, 2011). Distance learning has become a widespread and growing phenomenon, giving institutions a considerable boost to the use of information and communication technologies (ICT). The question during this difficult period is not about whether distance teaching-learning strategies could give quality and good standards of education, but on how educational institutions can embrace e-learning in such a significant way (Carey, 2020). Therefore, institutions of learning can choose to switch their plan of action from standard learning to the constructive option of embracing online learning with no or little option left. The change needs to be well prepared and decently built to ward off the lockdown or as called movement-controlled order from causing more complications (Irawan, Dwisona \& Lestari, 2020).

As a result, this literature review will begin to explore the question on what the effective teaching and learning activity is used during this pandemic. Then, the review of literature will continue to identify the challenges of online learning especially involving the students. An overview on challenges of online teaching and learning are followed by a look at the psychological impacts of online learning. It cannot be ignored that notwithstanding the multiple intensifying and continuous measures taken by the government to minimize Covid-19 cases, there will still be public fear, resulting in mental instability. They suffer from anxiety of contacting the virus, feeling powerless and strong negative stigma, in line with research that says coronavirus affects some people emotionally (Kumar \& Somani, 2020). This section aims to identify the academic stress influenced by the disastrous pandemic and sudden changes of learning methods. In addition to the economic and social consequences, the acceptance of the modern "e-learning" educational system by students within educational institutions is a dilemma (Al-Okaily et al., 2020). As of that, the study also highlights the challenges and acceptance among universities students under the Covid-19 conditions. The review paper ends with recommendations for future study.

\section{METHODOLOGY}

In the selection of references for this literature review, several databases were used. In order to take an initial sample of what sort of article was available, Google Scholar was used. Initially, broad search terms were used to draw up a list of study papers that were primary source and peer-reviewed. Variety of words and phrases searched included online learning, e-learning during Covid-19 and impacts of online learning due to the pandemic using Google Scholar. 
The data was collected using keywords in English. Then the following specialized database sources, such as Springer, Wiley, Elsevier, Web of Science and EBSCOhost, were systematically searched. When using other databases, better selection of more refined terminology was able to be used. As a result, to provide more specific options, articles from ResearchGate, ScienceDirect and SAGE were also chosen. Reports, search engines, scholarly articles, scientific papers and other academic publications are secondary sources of data used. Using tables in correlation with subtopics contained in the papers collected, sources were analyzed and divided accordingly. In the collected articles, data found is most compatible with the objective of my review paper. In this literature review paper, the related sources of previous studies have been considered. Most of the sources mentioned were cited within last year.

\section{LITERATURE REVIEW FINDINGS AND DISCUSSION Online Teaching and Learning: An overview}

A specific challenge has been the immediate and unexpected call for prior face-to-face university courses to be conducted online. With the support of digital technology, online teaching and learning requires many ways of designing and arranging greater learning perspectives and building distinctive learning environments (Rapanta et al., 2020). Student satisfaction represents how their education experience is perceived by learners. As recent studies have shown, some of the key problems found by university teachers with regard to web-based courses arise from its complexity of the education setting and shortcomings in planning and organization. A plethora of guidance directed at teachers has emerged from the Covid-19 crisis (Bates, 2020). Most of the recommendation focuses on instruments and tools that can be used by teachers to replace their face-to-face lessons.

\section{- From Teachers' View}

There are several studies that demonstrate similar findings that there is a lack of contact between students and educators, difficulty providing students with guidance, difficulty teaching according to the students' individual preferences and abilities, unable to provide teaching skills, lack of encouragement for students during online learning. From the other hand, some of the educators said that they expected no shift in the reduction in the need for formal or face-to-face education, a rise in the need for online learning environments, no need for formal education, and equal opportunities for all students through online education in line with research conducted by Ranasinghe, Karunarathna and Pradeepamali (2020), Cunningham and Anzola (2019). Online teachers, however, demonstrated that despite limited experience in distance learning, such as technological skills, time management, expertise and attitude in online education, they were still able to deal with patterns of distance learning (Markova, Glazkova, \& Zaborova, 2017). Moreover, according to Korkmaz and Toraman in 2020, Turkey's educators believe that certain measures must be taken against a potential outbreak in the future because there may be a pandemic like Covid-19 again and they may return to online teaching.

- From student's view

Students were advised to be more independent in both recognizing orientation signals and working with no micro-scaffolding. In view of the use of effective communication and efforts to promote better student involvement, online teaching 
requires more thorough assessment. The student's role is to become the master of his or her education process and to become increasingly independent (Rondriguez \& Cano, 2007). The importance of interaction has been emphasized by a variety of researchers. Trying to ensure success in web-based learning requires thoughtful design, active involvement of learners and outstanding communication skills. A central factor in student performance and fulfillment is self-efficacy. Students with higher self-efficacy do not view challenging tasks as complexities to be eliminate, but rather as a motivation and opportunity to grow their competency, compared to a low self-efficacy student; this may increase learning performance and success which lead to greater contentment with the results obtained (Alqurashi, 2019). In comparison to more recent research, former studies appeared to identify a substantial link within self in technology. They also noticed that students who were enrolled had a greater level of learning than students who were enrolled in the online course because it was not delivered in face-to-face mode because of the ease and versatility of the online course.

- Role of the participants

From a post-digital viewpoint, online learning has created a gap between content, technological and individual experience (Fawns, 2019). In ensuring the most out of the options offered by online educational systems, instructional strategies and management play a vital role (Anderson et al. 2011). Remote emergency education enabled by Covid-19 is very often modified rapidly, with no infrastructural support assured or sufficient. Despite this inadequate infrastructure, a large part of the initial help and assistance provided to non-expert online teachers was focused on the technological resources that are available at each institution and considered adequate to facilitate the transition (Rapanta et al., 2020). The growth of mobile device adoption has widened the arena of platforms for e-learning. Integrating virtual communities with online learning through a mobile platform will encourage student participation, resulting in greater learning outcomes. This perspective provides guidance on solving the crisis for students, institutional leaders, and officials.

An integral part of practical preparedness, though not the first one is online training. Institutions should engage more than ever before in the professional progression of their faculty in order to update their teachers on successful strategies or approaches of using online technology. The growth of online learning in tertiary education will intensify further and schools will coordinate themselves more systematically to pursue the most beneficial aspects of technology-based learning (Daniel, 2020). Given the lack of direct or person-to-person contact, the educatorss reviews and comments are important in e-learning environments. To put it another way, the study emphasis should shift from self-efficacy to the use of technology to the confidence of students in their ability to effectively perform, interact, study and accomplish a complete online course. The findings of the previous study showed that self-efficacy of online learning, engagement between learner and content, and interaction between learners and educators are important elements in satisfaction of students and perceived learning. The results also stress the significance of self-efficacy in online learning.

There seem to be a range of methods wherein educators could contribute to create the virtual education experience more engaging and functional. Learning by providing or finding good tools and on the other hand, be able to take advantage of them, requiring 
learners to read more autonomously (Rapanta et al., 2020). In addition, teachers are advised to open additional channels of communication just so learners could consistently receive the main message and ensure that they continue to inquire and listen because their wants can grow and their potentiality to express their demand. Therefore, faculty should slow down their speech properly in online teaching to allow students to catch key information points (Bao, 2020). Because of the low concentration characteristics of students in online learning, adjusting the teaching pace is necessary to ensure the efficient delivery of teaching material. The lack of human interaction is one of the downsides of online education (Graham, Henrie, \& Gibbons, 2006) that can lower the degree of contentment and fulfillment. Personalization features in e-learning systems have started to overcome this constraint. Self-efficacy scores improve the perceived level of satisfaction and actual success in customized distance learning, where learning mediums or materials are given as per to each individual's intellectual skill and design (Xu, Huang, Wang, \& Heales, 2014). Study results have shown that engagement is encouraged when requirements such as on problem-centered learning with consistent presentations, peer engagement between individuals, active learning activity, accessibility and enthusiasm for teachers and the use of useful course tools are connected (Hew, 2016).

The problem of managing the increasing growth of online users and content can be managed by the use of cloud storage services. Without a major investment in infrastructure or applications, cloud computing offers companies with a way to develop their IT capabilities. Low in cost, extensibility, centralized cloud storage, no user-side maintenance (no software required), simple monitoring, availability and recovery are the advantages of cloud computing, and the challenge is that it needs high speed and stable internet connectivity and security issues and confidentiality (El Mhouti, Erradi, \& Nasseh, 2018). Ease of use, utility, and security are the key factors for cloud computing adoption in e-learning (Kayali, Safie, \& Mukhtar, 2016). The Fully Online Learning Community (FOLC) pursues the creation of interpersonal relationship-building learning environments, encourages distributed accountability for refining knowledge through challenging feedback that causes cognitive dissonance, and promotes divergent thinking. In addition, FOLC provides well-established methods to pick and use digital affordances to facilitate fully online group learning (Van Oostveen et al., 2018). With all the logistical and technological challenges involved, academic staff of all backgrounds had to prepare and execute their lessons from home, and even without adequate technical assistance (Hodges, Moore, Lockee, Trust, \& Bond, 2020). Both learners and educators need to see the importance of how it works and have faith in the medium and the different online platforms to excel in online education (Moawad, 2020).

\section{Challenges}

The Covid-19 pandemic has raised huge challenges for the higher education sector globally. It has been recognized that education in this country shall implement an extensive digitalization to address the needs of the young generation and their digitally enhanced future. The Covid-19 pandemic unexpectedly and suddenly forced institutions and education to take part in such a change (Iivari, Sharma, \& Ventä-Olkkonen, 2020). Students use a variety of digital devices such as laptops, tablets and phones or smartphones to facilitate informal learning (Murphy et al., 2014). Mobile learning presents both opportunities and challenges; it offers learning flexibility; on the other hand, for someone who does not have connection and accessibility to these gadgets, it is a constraint. There are a range of different education technologies available, but sometimes they present a lot of challenges (Dhawan, 2020). E-learning deals with many 
obstacles, varying from problems for students, problems for lecturer, and problems with content issues. For teachers, it is a struggle to transition from physical to virtual mode, adapt their methods of teaching while managing their time. However, research by Korkmaz and Toraman (2020) shows that during their online learning activities, most educators faced some issues, anticipating some improvements in educational practices after Covid-19 happened and believing that important steps need to be taken in the education system against another possible virus outbreak in the coming years.

\section{Technology difficulties}

In relation to the unified theory of acceptance and use of technology, it is noted that the acceptance and use of technology is affected by expectations of accomplishment, expectations of engagement, social effect and conditions of facilitation. Some technology inhibitors also have a different presence and have a negative effect on the acceptance of technology. They are pervasiveness, repetition of effort, network instability, information overload, unnecessary demands for information, and manipulation that negatively impact system and information quality intentions of use (Panigrahi, Srivastava, \& Sharma, 2018). The compatibility of the online learning method is positively tied to its acceptance. In addition, the rate of acceptance relies on the efficiency of the technology to be implemented and less ambiguity to use. In view of the critical difficulties of online learning during Covid-19, it is up to students and instructors to find ways to adapt to the current situation.

These difficulties and issues related to digital technology vary with downloading problems, installation difficulties, login errors, video and audio issues, and so forth. There is absence of consistency, quality assurance, e-resource creation, and e-content distribution standards. There are several technological difficulties that can cause disruption or delay in a specific mission. Online mode has its own specifications (Bisht, Raj \& Jasola, 2020). The key downside of the synchronous mode is that teaching conveyance performance heavily relies on the consistency of the Internet connection speed. During live sessions, a poor link can lead to disturbances, and this influences the performance or efficiency of delivery of the course. This difficulty is more pronounced for students with minimal Internet access in rural areas, or those who are unable to afford costly subscription of network plans and will have to depend on a traditional Internet pay-as-you-go SIM card network plan. This issue needs to be addressed urgently to allow all to benefit from quality education through e-learning (Cojocariu, Lazar, Nedeff, \& Lazar, 2014).

In this tough era, ensuring digital equity is crucial. Both wireless networks, the Wi-Fi and digital devices are not open to both teachers and students. The lack of sufficient digital resources, no Internet access or Wi-Fi connections will bring about a lot of problems because many learners can miss learning opportunities (Dhawan, 2020). For instance, Bhusal and Rimal (2020) claim that many of Nepal's teachers and students in higher education argue that the results of the current study are not supported by a proper internet link. In the context of person-to-person lectures, teachers have become acquainted with conventional teaching methods, and so they refuse to consider any improvement. But in the middle of this crisis, they have no other choice but to adjust to the complex environment and embrace the transition. For the education sector, it would be helpful and will carry a lot of unexpected developments. In addition, the delivery modes for e-learning will shift from synchronous learning to asynchronous learning. Using video-conference platforms is crucial for synchronous learning. Most applications, however, provide minimal features as a free time kit. Intermittent Internet 
access seriously restricted the student-engagement activities as it hindered involvement and was kind of an anti-climax (Azlan et al., 2020).

\section{Personal issues}

Personal focus is a major problem facing online learning as well. Learners want two-way communication that is hard to enforce at times. The financial limitation of not even being able to purchase a communication device or a laptop was also reported by a small percentage of students (Bisht, Raj \& Jasola, 2020). As long as students implement what they understand, the learning process may not achieve its objectives. In a research, students have been found not to be properly prepared in a virtual learning environment to align their jobs, family, and social engagement with their study life. Students have also been identified to be inadequately equipped for many e-learning skills sets and capabilities of the educational type. There is also a low rate of readiness between learners for the use of e-learning systems (Parkes, Stein, \& Reading, 2015). Another critical problem for students is that the everyday activities of student life have also been totally changed because they now have to participate in online learning. There are now few options for the anxious student who attempts to relieve themselves by interaction with colleagues.

Some learners found online learning content recording were not very engaging. Moreover, particular problems for those with family commitments did not have time to focus on the changes that happened. For students who shelter in environments which are less convenient and more psychologically and physically isolating and may not even be very accommodating to learning and achievement, this radical change to online education may also be more challenging (Besser, Flett \& Zeigler, 2020). Some learners are not willing to pay for the full access of synchronous learning video conferencing apps unless the college is willing to pay the cost to operate under the affordable internet plan constraints. This finding is also associated with the research findings of Akyildiz, Kak, and Nie (2020), where he finds that the challenges faced by students in the online mode of education are the lack of communication and interaction that encourage students to loneliness, exam concerns, conventional educational habits, the overload of assignments, and management skills. Students experienced a decline in wellbeing, lack of motivation, trouble concentrating on their studies and Internet access issues with regards to difficulties faced due to the change from face-to-face learning to a full virtual learning environment (Azlan et al, 2020).

Internet accessibility and lack of communication with peers, lecturers and faculty staff was identified as some of the online education issues and challenges (Bisht, Raj \& Jasola, 2020). There are several aspects to the Covid-19 pandemic that cause it particularly overwhelming for students. Students agree that the lack of interaction, technological issues and difficulties in interpreting teaching objectives are the biggest obstacles to e-learning (Song et al., 2004). Students who do not have access to all digital technology should not be neglected and forgotten. Such students are less wealthy and belong to less tech-savvy families with limitations on financial capital, so when classes take place online, they can miss out. Because of the huge costs related to digital devices and online data plans, they may miss out. This income gap will widen inequality gaps (Dhawan, 2020). Despite these factors, the variability remained of such significance that it is evident that for many students, the drastic advent of synchronous online learning demanded by the disease outbreak was relatively unfavourable. They were expected to be more competent and conscious in their learning methods by the new learning standard. 


\section{Psychological Impacts}

Previous research found that disease outbreaks affected human mental health and well-being. It discussed several risk factors. The World Health Organization announced a public global medical crisis of a worldwide concern on 30 January 2020 (WHO, 2020). This global medical crisis does not just affect the overall fitness physical health of individuals, but it also has a huge effect on their psychological health (Wang et al., 2020; Huang, \& Rong, 2020; Huang et al., 2020). Notwithstanding numerous proactive initiatives being done by the authority that rule the countries affected by the outbreak to reduce Covid-19 virus transmission, there will still be community apprehension, resulting in erratic behavior (Irawan, Dwisona and Lestari, 2020). This pandemic not just carries the chance of death from infectious infection, but also psychological problems for individuals around the globe (Cui et al., 2020). In addition, Liu et.al. (2020) found that women showed greater stress, anxiety and depression compared to men in the first two weeks after the outbreak. Pape (2010) notes that many researchers and educators are interested in e-learning to strengthen and optimize the virtual learning outcomes of students while countering resource reduction, especially in higher education. The urgent imperative triggered by the ongoing Covid-19 pandemic to migrate online has increased the pressures and work overload faced by university lectures and employees who have ever since struggled to balance their teaching, study and work responsibilities. This is supported by studies demonstrating that global health crises could have several psychological impacts on learners, that can be reflected throughout the expression of distress, anxiety and insecurity (Sharp \& Theiler, 2018).

Nevertheless, the rising percentage of patients and confirmed cases, and also the increasing list of countries infected by the epidemic, have sparked concerns about the world becoming contaminated by this pandemic, which has raised fear, anxiety and stress (Bao, Sun, Meng, Shi, \& Lu, 2020). At all levels, governments and educational institutions are making considerable efforts to find realistic alternatives to online learning in the wake of the Covid-19 outbreak (Irawan, Dwisona \& Lestari, 2020). According to a College of Education survey, $32 \%$ of 646 male students showed confusion about their evaluation, $17 \%$ had issues with the usability of using online platforms, while 438 out of 1625 female students reported the concerns they faced after moving to online learning. The findings show that the biggest stressor impacting students is the confusion they experience about the tests, the end of the semester, and their evaluation (Al Ateeq et al., 2020). Moreover, this confusion may cause people to experience psychological distress, resulting in tremendous psychological stress that aggravates symptoms of Posttraumatic Stress Disorder (PTSD). Since occurrences are unpredictable, individuals may be puzzled about their present situation and unsure about their future (Yates \& Stone, 1992).

The frequency and performance of tests, large curricula, parental pressure, loneliness, and concern for the future are other causes of stress (Al Ateeq, Aljhani, \& AlEesa, 2020). Cut down aspirations to decrease anxiety. Students will have to adjust to modernize learning and teaching approaches at the same time and cope with all the practical difficulties and psychological impact due to the virus outbreak and its accompanying lockout (Yazid \& Lie, 2020). Owing to the rapid introduction of this online teaching "migration" during the outbreak of Covid-19, the students' anxiety needs to be alleviated in various ways to make sure that they too can actively and conclusively participate in e-learning. If they are forbidden to leave the house without physical games and without contact with their friends, the situation will get worse. Bored, depressed, scared of getting the viruses, inaccurate information (hoaxes) 
may also be spread, and family financial circumstances may worsen. Anxiety then happens and worsens when there is no direct interaction (Galea, Merchant, \& Lurie, 2020).

Besides, distance learning has also been found to be related to stress due to academic, financial and social issues (Al Ateeq., et al, 2020). Stress-related disorders and suicide are associated with uncertainty, especially economic uncertainty. Uncertainty has been found to be a more difficult state to be in than knowing that anything terrible would actually happen. Uncertainty is associated with anxiety and depression (Sher, 2020). Research also indicates that the stability of household income is also a key factor in the deprivation encountered by students during the Covid-19 crisis, that can be clarified by elevated economic and social stress (Liu, 2013). This is confirmed by the findings of previous studies that showed that human beings were anxious about future employment during the Covid-19 outbreak, particularly in financially disadvantaged families (Yazid \& Lie, 2020). Past study revealed data on internet quotas buying grievances which need to be used for e-learning. Learners are concerned regarding their guardian income, that is reduced due to the social distancing policy which allows their guardian or parents to be at home in order to control their income. Students whose parents are economically capable are ultimately controlled by access to online learning. Students coming from below-average family financial environments, on the other hand, feel nervous since they cannot actually afford an access quota, depending on the final score of the education program. About equipment. The low correlation indicates that depression, anxiety and stress not only rely on the family's financial capital but are also connected to a family's socio-economic status. In fact, it can be noted that individuals with good or high socio-economic status can get ample supplies, making them less vulnerable to psychological distress (Rehman et al., 2020).

The novelty of the virus itself and the unpredictable nature and uncertainty of when the situation is fully controlled has placed people under unnecessary stress, especially when the situation is completely controlled. Face-to-face social connections are lost (Al Ateeq, Aljhani, \& AlEesa, 2020). Since biological, psychological and social beings are all human beings (Korkmaz \& Toraman, 2020) and learning requires more than these variables, online learning alone does not fulfil all student learning needs. Universities around the world can instigate a range of steps to help minimize the negative psychological effect of the situation on their students, such as having proper online academic advisers, as well as psychological advice for their mental wellbeing, as the Covid-19 pandemic travels from nation to nation. Faculty members should be educated on how to implement new appraisal approaches to be used by their students and introduce technology when paying attention to the perspectives and successful learning of their students (Li, Sahu, Talwalkar, \& Smith, 2020). A solution-oriented attempt to address the psychological effects of the Covid-19 pandemic is recommended for future researchers.

\section{CONCLUSION}

The contribution of the paper can be summed as identifying the reasons analyzed for adoption, continuation, learning outcomes in an online world, and offering potential research guidance for educators and managers to gain maximum benefits by effectively integrating technology on online platforms. The educator's task would be to provide each student with encouragement, guidance and support as per their specifications, offer formative and 
summative evaluations, ensure that learners make progress, inspire students and enable them to implement what they have learned (Moore, 1989). This disease outbreak has already shown us that digital literacy skills and the use of technology in education are no longer an option, but a requirement. To strengthen learning delivery and increase the measure of student participation, an effective and enriched approach to online instructional delivery and online interactive learning resources must be explored. To cope with the challenges, all educators should revise their pedagogical skills. Institutions, instructors and students should also strive to look for diverse settings to fix the damage done by disruptions to learn paths caused by Covid-19. The most important thing to remember here, though is that no matter what online tools or programs have been used, when attempting to address an educational question, we should be careful not to trigger a bigger problem. In addition, we should not ignore the psychological and social or socio-emotional dimensions of learning that involve a more comprehensive perspective when attempting to ensure the student's academic progress.

The most important point to remember here however, is that when trying to fix an educational issue, regardless of what online resources or services have been used, we should be careful not to create a bigger problem. Furthermore, in seeking to ensure the academic success of the student, we should not neglect the psychological and social or socio-emotional aspects of learning that require a more detailed perspective. A comparison between fully online and mixed courses may be conducted in future research to see how the findings vary. Student demographic factors should be included in future studies when comparing outcomes. In other words, we should not ignore the psychological and social or socio-emotional dimensions of learning, which involve a more holistic viewpoint, when trying to ensure the student's academic progress. Studies should be performed with learners on e-learning activities during the Covid-19 outbreak, as an agenda for more study on online learning. Since the students' online learning experience during this pandemic does not have the same outcomes as the related research performed before this global outbreak.

In parallel, additional research on the achievement of learning during the coronavirus epidemic should be performed on various school topics. Such research may provide evidence to determine which topics are more appropriate for online learning. Further studies may explore initiative or any potential to enhance the efficiency of student's interaction and design practices that students would gain benefit from. More on the preparations that systems should make and the needs of students at various levels and stages should be studied in further study. Video streaming services that provide various video formats and resolutions can be explored to overcome this constraint. Future studies should examine the effects on the educational system of the Covid-19 pandemic and gather scientific information on how educational institutions can react efficiently to another future outbreak of the virus. To produce evidence-based mental health strategies during emergencies, further studies are required to perform longitudinal evaluations of psychological conditions such as depression and anxiety.

\section{REFERENCES}

Akyildiz, I. F., Kak, A., \& Nie, S. (2020). 6G and beyond: The future of wireless communications systems. IEEE Access, 8, 133995-134030. Retrieved from https://ieeexplore.ieee.org/ abstract/document/9145564 
Al Ateeq, D. A., Aljhani, S., \& AlEesa, D. (2020). Perceived stress among students in virtual classrooms during the Covid-19 outbreak in KSA. Journal of Taibah University Medical Sciences, 15(5), 398-403. doi: 10.1016/j.jtumed.2020.07.004

Al-Okaily, M., Alqudah, H., Matar, A., Lutfi, A., \& Taamneh, A. (2020). Dataset on the Acceptance of e-learning System among Universities Students' under the Covid-19 Pandemic Conditions. Data in brief, 32, 106176. doi: 10.1016/j.dib.2020.106176

Alqurashi, E.(2019).Predicting student satisfaction and perceived learning within onlinelearning environments. Distance Education, 40(1), 133-148. doi: 10.1080/01587919.2018.1553562

Anderson, T. (2011). Towards a theory of online learning. In T. Anderson (Ed.), The theory and practice of online learning, 2, 45-74. Edmonton: Athabasca University Press. doi: 10.24059/olj.v5i2.1875.

Azlan, C. A. et al. (2020). Teaching and learning of postgraduate medical physics using Internet-based e-learning during the Covid-19 pandemic: A case study from Malaysia. Physica Medica, 80, 10-16. doi: 10.1016/j.ejmp.2020.10.002

Bao, W. (2020). Covid-19 and online teaching in higher education: A case study of Peking University. Human Behavior and Emerging Technologies, 2(2), 113-115. doi: 10.1002/ hbe2.191

Bao, Y., Sun, Y., Meng, S., Shi, J., \& Lu, L. (2020). 2019-nCoV epidemic: address mental health care to empower society. The Lancet, 395(10224), 37-38. doi: 10.1016/S0140-6736(20)30308-3

Bates, A. W. (2020). Advice to those about to teach online because of the corona-virus. Tony Bates. Retrieved from https://www.tonybates.ca/2020/03/09/advice-to-those-about-toteach-online-because-of-the-corona-virus/

Besser, A., Flett, G. L., \& Zeigler-Hill, V. (2020). Adaptability to a sudden transition to online learning during the Covid-19 pandemic: Understanding the challenges for students. Scholarship of Teaching and Learning in Psychology. doi: 10.1037/st10000198

Bhusal, S., \& Rimal, S. (2020). Challenges of online learning in Nepal. Retrieved from https:// www.researchgate.net/publication/341901335_Challenges_and_Possibilities_ of_Online_Education_in_a_Developing_Country_with_Special_Focus_on_ Nepal

Bisht, R. K., Jasola, S., \& Bisht, I. P. (2020). Acceptability and challenges of online higher education in the era of Covid-19: a study of students' perspective. Asian Education and Development Studies. doi: 10.1108/AEDS-05-2020-0119

Carey, K. (2020). Everybody ready for the big migration to online college. Actually, No. Retrieved from, https://www.nytimes.com/2020/03/13/upshot/coronavirus-onlinecollege-classes-unprepared.html

Cojocariu, V. M., Lazar, I., Nedeff, V., \& Lazar, G. (2014). SWOT anlysis of e-learning educational services from the perspective of their beneficiaries. Procedia-Social and Behavioral Sciences, 116, 1999-2003.

Cui, L. B., Wang, X. H., \& Wang, H. N. (2020). Challenges of facing coronavirus disease 2019: Psychiatric services for patients with mental disorders. Psychiatry and Clinical Neurosciences. doi: 10.1111/pcn.13003

Cunningham, P., \& Anzola, G. (2019). Editorial Note. The shifting mind set of the higher education internationalization landscape. ObIES, 3. Retrieved from https://revistas. udistrital.edu.co/index.php/obies/article/view/16163/15552 
Daniel, S. J. (2020). Education and the Covid-19 pandemic. Prospects, 1-6. doi:10.1007/s11125020-09464-3

Dhawan, S. (2020). Online learning: A panacea in the time of Covid-19 crisis. Journal of Educational Technology Systems, 49(1), 5-22. doi: 10.1177/0047239520934018

El Mhouti, A., Erradi, M., \& Nasseh, A. (2018). Using cloud computing services in e-learning process: Benefits and challenges. Education and Information Technologies, 23(2), 893-909. doi: 10.1007/s10639-017-9642-x

Fawns, T. (2019). Postdigital education in design and practice. Postdigital Science and Education, 1(1), 132-145. doi: 10.1007/s42438-018-0021-8.

Galea, S., Merchant, R. M., \& Lurie, N. (2020). The mental health consequences of Covid-19 and physical distancing: The need for prevention and early intervention. JAMA internal medicine, 180(6), 817-818. doi: 10.1001/jamainternmed.2020.1562

Graham, C. R., Henrie, C. R., \& Gibbons, A. S. (2013). Developing models and theory for blended learning research. Blended learning: Research perspectives, 2, 13-33. Retrieved from https://books.google.com.my/books?hl=en\&lr=\&id=JfMJAgAA QBAJ\&oi=fnd \&pg=PA13\&dq=graham $+2006+$ blended+learning\&ots=LB0WiJsDJ\&sig=J8QvLF4wnAKxVXwaumNzwp5UT-8\&redir_esc=y\#v=onepage\&q=graham $\% 20$ $2006 \%$ 20blended $\%$ 20learning\&f=false

Hew, K. F. (2016). Promoting engagement in online courses: What strategies can we learn from three highly rated MOOCS. British Journal of Educational Technology, 47(2), 320-341. doi: 10.1111/bjet.12235

Hodges, C., Moore, S., Lockee, B., Trust, T., \& Bond, A. (2020). The difference between emergency remote teaching and online learning. Retrieved from https://er.educause. edu/articles/2020/3/the-

Huang, L., \& Rong L., H. (2020). Emotional responses and coping strategies of nurses and nursing college students during Covid-19 outbreak. MedRxiv. doi: 10.1101/2020.03.05.20031898

Huang, R., Tlili, A., Chang, T. W., Zhang, X., Nascimbeni, F., \& Burgos, D. (2020). Disrupted classes, undisrupted learning during Covid-19 outbreak in China: application of open educational practices and resources. Smart Learning Environments, 7(1), 1-15. Doi: 10.1186/ s40561-020-00125-8

Iivari, N., Sharma, S., \& Ventä-Olkkonen, L. (2020). Digital transformation of everyday lifeHow Covid-19 pandemic transformed the basic education of the young generation and why information management research should care? International Journal of Information Management, 55, 102183. Doi: 10.1016/j.ijinfomgt.2020.102183

Irawan, A. W., Dwisona, D., \& Lestari, M. (2020). Psychological impacts of students on online learning during the pandemic Covid-19. KONSELI: Jurnal Bimbingan dan Konseling (E-Journal), 7(1), 53-60. Doi: 10.24042/kons.v7i1.6389

Kapasia, N., et al. (2020). Impact of lockdown on learning status of undergraduate and postgraduate students during COVID-19 pandemic in West Bengal, India. Children and Youth Services Review, 116, Doi: 10.1016/j.childyouth.2020.105194

Kayali, M. H., Safie, N., \& Mukhtar, M. (2016). Adoption of cloud-based E-learning: a systematic literature review of adoption factors and theories. J. Eng. Appl. Sci, 11(8), 1839-1845. 
Korkmaz, G., \& Toraman, Ç. (2020). Are we ready for the post-COVID-19 educational practice? An investigation into what educators think as to online learning. International Journal of Technology in Education and Science (IJTES), 4(4), 293-309. doi: 10.46328/ijtes.v4i4.110

Kumar, A. \& Somani, A. (2020). Dealing with Coronavirus anxiety and OCD. Asian Journal of Psychiatry, 102053. doi: 10.1016/j.ajp.2020.102053

Li, T., Sahu, A. K., Talwalkar, A., \& Smith, V. (2020). Federated learning: Challenges, methods, and future directions. IEEE Signal Processing Magazine, 37(3), 50-60. Retrieved from https://ieeexplore.ieee.org/abstract/document/9084352

Lin, C. H., Zhang, Y., \& Zheng, B. (2017). The roles of learning strategies and motivation in online language learning: A structural equation modeling analysis. Computers $\mathcal{E}$ Education, 113, 75-85. doi: doi.org/10.1016/j.compedu.2017.05.014

Liu, N., Zhang, F., Wei, C., Jia, Y., Shang, Z., Sun, L., ... \& Liu, W. (2020). Prevalence and predictors of PTSS during COVID-19 outbreak in China hardest-hit areas: Gender differences matter. Psychiatry Research, 287, doi: 10.1016/j.psychres.2020.112921.

Markova, T., Glazkova, I., \& Zaborova, E. (2017). Quality issues of online distance learning. Procedia-Social and Behavioral Sciences, 237, 685-691

Moawad, R. A. (2020). Online Learning during the COVID-19 Pandemic and Academic Stress in University Students. Revista Românească pentru Educație Multidimensională, 12(1 Sup2), 100-107. doi: 10.18662/rrem/12.1sup2

Moore, M. G. (1989). Editorial: Three types of interaction. American Journal of Distance Education, 3(2), 1-7. doi:10.1080/08923648909526659

Murphy, A., Midgley, W., \& Farley, H. (2014, November). Mobile learning trends among students in Vietnam. In international conference on mobile and contextual learning (pp. 197-204). Springer, Cham. doi:10.1007/978-3-319-13416-1_18

Nuere, S., \& de Miguel, L. (2020). The digital/technological connection with Covid-19: An unprecedented challenge in university teaching. Technology, Knowledge and Learning, 1-13. Retrieved from doi: 10.1007/s10758-020-09454-6

Panigrahi, R., Srivastava, P. R., \& Sharma, D. (2018). Online learning: Adoption, continuance, and learning outcome-A review of literature. International Journal of Information Management, 43, 1-14. doi: 10.1016/j.jinfomgt.2018.05.005

Pape, L. (2010). Blended teaching and learning. The Education Digest, 76(2), 22. Retrieved from https://facultycenter.ischool.syr.edu/wp-content/uploads/2012/02/blendedlearning-and-teaching.pdf

Parkes, M., Stein, S., \& Reading, C. (2015). Student preparedness for university e-learning environments. The Internet and Higher Education, 25, 1-10. doi: 10.1016/j. iheduc.2014.10.002

Paudel, P. (2020). Online education: Benefits, challenges and strategies during and after COVID-19 in higher education. International Journal on Studies in Education, 3(2), 70-85. doi: 10.46328/ijonse.32

Ranasinghe, R., Karunarathna, C., \& Pradeepamali, J. (2020). After Corona (COVID-19) Impacts on Global Poverty and Recovery of Tourism Based Service Economies: An Appraisal. Retrieved from https://papers.ssrn.com/sol3/papers.cfm?abstract_id=3591259

Rapanta, C., Botturi, L., Goodyear, P., Guàrdia, L., \& Koole, M. (2020). Online university teaching during and after the Covid-19 crisis: Refocusing teacher presence and learning activity. Postdigital Science and Education, 2(3), 923-945. doi: 10.1007/s42438-020-00155-y 
Rehman, U., Shahnawaz, M. G., Khan, N. H., Kharshiing, K. D., Khursheed, M., Gupta, K., \& Uniyal, R. (2020). Depression, anxiety and stress among Indians in times of Covid-19 lockdown. Community mental health journal, 1-7. Retrieved from doi: 10.1007/s10597-02000664-x

Rieley, J. B. (2020). Corona Virus and its impact on higher education. Research Gate. doi: $10.1177 / 0047239520934018$

Rodriguez, L., \& Cano, F. (2007). The learning approaches and epistemological beliefs of university students: a cross-sectional and longitudinal study. Studies in Higher Education, 32 (5), 647-667. doi:10.1080/03075070701573807

Sharp, J., \& Theiler, S. (2018). A review of psychological distress among university students: Pervasiveness, implications and potential points of intervention. International Journal for the Advancement of Counselling, 40(3), 193-212. doi: 10.1007/s10447-018-9321-7

Sher, L. (2020). The impact of the COVID-19 pandemic on suicide rates. QJM: An International Journal of Medicine, 113(10), 707-712. doi: 10.1093/qjmed/hcaa202

Song, L., Singleton, E. S., Hill, J. R., \& Koh, M. H. (2004). Improving online learning: Student perceptions of useful and challenging characteristics. The internet and higher education, 7(1), 59-70. doi: 10.1016/j.iheduc.2003.11.003

Van Oostveen, R., DiGiuseppe, M., Barber, W., Blayone, T., \& Childs, E. (2018, June). Exploring cross-cultural digital competencies: Building the Global Educational Learning Observatory, GELO. In EdMedia+ Innovate Learning, 357-364. Association for the Advancement of Computing in Education (AACE). Retrieved from https://www.learntechlib.org/p/184217/

Wang, H., Li, T., Gauthier, S., Yu, E., Tang, Y., Barbarino, P., \& Yu, X. (2020). Coronavirus epidemic and geriatric mental healthcare in China: how a coordinated response by professional organizations helped older adults during an unprecedented crisis. International Psychogeriatrics, 32 (10), 1117-1120.

WHO, (2020). Mental health and psychosocial considerations during the COVID-19 outbreak [Ebook]. Retrieved from https://www.who.int/docs/default-source/coronaviruse/ mental-health-considerations.pdf.

Xu, D., Huang, W. W., Wang, H., \& Heales, J. (2014). Enhancing e-learning effectiveness using an intelligent agent-supported personalized virtual learning environment: An empirical investigation. Information \& Management, 51(4), 430-440. doi: 10.1016/j.im.2014.02.009

Yates, J. F., \& Stone, E. R. (1992). The risk construct. Retrieved from https://psycnet.apa. org/record/1992-97821-001

Yazid, S., \& Lie, L. D. J. (2020). Dampak pandemi terhadap mobilitas manusia di Asia Tenggara. Jurnal Ilmiah Hubungan Internasional, 75-83. doi: 10.26593/jihi.v0i0.3862.75-83 